\title{
CHARLES COQUELIN AND JULES DUPUIT ON BANKING AND CREDIT
}

BY

\author{
GUY NUMA
}

\begin{abstract}
Charles Coquelin and Jules Dupuit both advocated free banking, but they articulated different views on credit, the note-issuing mechanism, and the role of banking in economic crises. For Coquelin, credit allowed producers to enhance their productive capacities. There was no need to restrict the issuing of banknotes to the quantity of metallic reserves. Coquelin emphasized the role that privileged banks played in the emergence of economic crises. For his part, Dupuit did not believe that credit could create more capital, and warned against the excessive issuing of banknotes. Dupuit considered economic crises to be caused by real factors. I argue that Coquelin's ideas reflected a credit theory of money while Dupuit's views were characteristic of a monetary theory of credit.
\end{abstract}

\section{INTRODUCTION}

In November 1863, Jules Dupuit expounded on his views about banking and credit before his peers of the Société d'économie politique (SEP), a learned society comprised of followers of Jean-Baptiste Say. During his address, Dupuit stated that "credit, as high as it can be, does not create the smallest quantity of capital ... especially when the opposite doctrine is vulgarized in the books of some economists" (SEP 1863, p. 338). According to Yves Breton and Gérard Klotz (2009, 2, p. 708n7), Dupuit was probably referring to the Scottish economist Henry D. Macleod. They could have also mentioned the name of Charles Coquelin, who was particularly influential in his role as co-editor of Dictionnaire de l'économie politique.

Guy Numa, Economics Department and Honors College, University of Massachusetts Boston, USA, guy.numa@umb.edu. I am grateful to Perry Mehrling, Ian Kumekawa, Nathaniel Donahue, two anonymous referees, and the editor of JHET for their insightful comments. 
Several reasons call for a comparison between Coquelin and Dupuit. Coquelin was a recognized theoretician regarding banking and credit, and represented the hegemonic opinion on the subject within the French liberal school. ${ }^{1}$ Like Dupuit, Coquelin was a French economist and a member of SEP. Moreover, his 1848 magnum opus, Du crédit et des banques, preceded the first volume of Macleod's Theory and Practice of Banking, which was published in 1855. Coquelin's fellow economists quickly adopted his book as the main reference on banking and credit (Nataf 2006). It therefore seems more natural to contrast Dupuit's positions with those of Coquelin.

Breton (1991) and Claire Silvant (2010) discuss some of the themes developed in the present article but, to this date, no study has compared Coquelin's and Dupuit's arguments with respect to banking and credit. Yet, a study of these two representative figures of the French liberal school enhances our understanding of the diverging viewpoints among the free banking supporters. Furthermore, Oskari Juurikkala (2002) erroneously claims that the debate of fractional reserve vs. $100 \%$ reserve banking among the pro-free banking French economists originated in 1866; he thus overlooks Coquelin's writings and the SEP meetings of November 1863 that Dupuit attended. Thus, the existing literature on this issue is scarce and unsatisfactory. The present essay gives a more complete account of the debates over the design and functioning of the banking system and over the role of non-metallic circulation in nineteenth-century France.

The purpose of this essay is to analyze and compare the ideas developed by Coquelin and Dupuit on banking and credit. Coquelin and Dupuit both supported free banking, ${ }^{2}$ but they articulated different views on three points: the relationship between credit and capital, ${ }^{3}$ the note-issuing mechanism, and the role of banking in economic crises. ${ }^{4}$ For Coquelin, credit—a means of delaying final settlement by promising to pay money - allowed producers to enhance their productive capacities and thereby develop the economy. There was therefore no need to restrict the issuing of banknotes to the quantity of metallic reserves. Coquelin emphasized the role that privileged banks (with the exclusive right to issue banknotes) played in the emergence and recurrence of economic crises. By contrast, Dupuit did not believe that credit could create more capital, and warned against the excessive issuing of banknotes. Dupuit considered economic crises to be caused first and foremost by

\footnotetext{
${ }^{1}$ The term "liberal" is used here in the European sense in reference to nineteenth-century economists who believed that the free market was more effective than government intervention. These are also known as the "Paris Group" (Schumpeter 1954, pp. 840-843). See Breton and Lutfalla (1991), Arena (2001), and Leter (2006). In general, the French liberals held meetings at SEP and frequently contributed to the Journal des économistes.

${ }^{2}$ My essay addresses only the positions of these two prominent supporters of free banking. The debate about central vs. free banking within the French liberal school is beyond the scope of this article. For more information, see Smith (1936), Breton (1991), Domin (2007), and Silvant (2010).

3In this article, "capital" refers to commodities (capital goods) or sums of money (capital funds) used as investment in order to produce other goods.

${ }^{4}$ The French liberals characterized crises in terms of their manifestations and impacts, which could be confusing for modern readers. The most common expressions were "panics," "commercial crises," "financial crises," "monetary crises," or "states of distress," among others. In this paper, I opt for the generic term "economic crises."
} 
real factors. I argue that Coquelin's ideas reflected a credit theory of money, while Dupuit's views were typical of a monetary theory of credit. ${ }^{5}$

According to Joseph Schumpeter (1954, p. 717), the monetary theory of credit means that money remains at the analytical foundation of credit, since the settlement of each payment and each loan has to occur in money. Simply put, although credit may temporarily replace money, final settlement must take place in money. This was the position defended by Dupuit during the November 1863 meetings (SEP 1863, p. 340). Coquelin's views, however, were characteristic of a credit theory of money. A credit theory of money entails a clearing system that cancels claims and debts and carries forward the differences so that "money" payments come in only as a special case. Money fundamentally arises from credit. As a result, monetary flows affect real variables, which presupposes an endogenization of the money stock. Coquelin championed this conception in various writings (Coquelin 1842, 1848, 1852b).

The interest of this article is threefold. First, it illustrates the theoretical divergences among the proponents of free banking in nineteenth-century France. ${ }^{6}$ Although they agreed on the merits of a competitive and decentralized system, they defended heterogeneous positions with regard to the role and practice of the banking industry. In particular, the essay sheds greater light on the divergence concerning the interaction between banking and economic crisis. Second, I show that the contrasting views of Coquelin and Dupuit predate a debate revolving around similar issues that occurred in $1866,{ }^{7}$ a point that previous analysts failed to notice. Third, the article confirms that Dupuit did not hesitate to be in the minority, a common situation for him. ${ }^{8}$ This corroborates the idea that he was a maverick increasingly at odds with his colleagues (Breton and Klotz 2009).

Before delving into the topic at hand, I should mention some caveats regarding Dupuit's views on banking and money. Reconstructing his ideas can be difficult for two reasons. First, unlike Coquelin, Dupuit did not author any article or book

\footnotetext{
${ }^{5}$ The reader may resort to the Currency vs. Banking School opposition to characterize the banking debates in nineteenth-century France. This perspective is inappropriate for many reasons. Historically speaking, the aforementioned opposition was specifically applicable to the banking debates in Britain. Additionally, the focus on the opposition between Currency and Banking schools overshadowed a third group, the supporters of free banking (Schwartz 1989; Arnon 2011). In France, the free banking advocates were by far the most dominant and the most vocal. The present article—being concerned with two, prominent, free banking supporters-reflects that rapport de force. The French debates were unique because, unlike similar debates in Britain, free banking was the central issue in France and was associated with both monetary theory of credit and credit theory of money, as shown throughout the analysis of Coquelin's and Dupuit's arguments.

${ }^{6}$ For a modern discussion of free banking, see, for instance, Dowd $(1988,1992)$ and White ([1995] 2008). See also Carr and Mathewson (1988), Sechrest (1988, 2008), and Cowen and Kroszner (1989) for dissenting views on free banking in nineteenth-century Scotland.

${ }^{7}$ The debate saw Henri Cernushi and Victor Modeste on one side, and Jean-Gustave Courcelle-Seneuil on the other. Michel G. P. Du Puynode and Théodore Mannequin also participated in the debate. Cernuschi $(1865,1866)$ and Modeste $(1866 a, 1866 b)$ suggested that all banknotes in excess of metallic reserves were inflationary and equal to false money. Courcelle-Seneuil (1866) replied with a praise of credit and fractional reserve banking. This debate was a resurgence of previously discussed matters, as demonstrated in the present essay.

${ }^{8}$ The same can be said about his views on property rights or the methodology of political economy, for instance.
} 
specifically concerned with the subject matter. Therefore, modern readers must rely on two primary sources published between 1855 and 1865: the recorded minutes of his participation in the SEP meetings, and some passages of La liberté commerciale, his only book on political economy. ${ }^{9}$ Second, like many of his contemporaries, Dupuit did not consistently cite his sources (Poinsot 2011). Sometimes Dupuit referred to other authors without naming them. ${ }^{10}$ As a result, one may conclude that Dupuit's analysis was incomplete.

The text is structured as follows. The following section provides some background information in order to properly contextualize the ideas of Coquelin and Dupuit. Section III examines the relationship between credit and capital, and the note-issuing mechanism. Section IV deals with the role of banks in economic crises. The closing section makes some concluding remarks.

\section{FROM LAW AND ENGINEERING TO POLITICAL ECONOMY}

Coquelin and Dupuit shared a common thread: they were self-taught economists, resolute free traders, and free banking supporters. However, they differed in their personal and professional trajectories. Those differences may explain why their views on some theoretical and policy issues diverged despite a fundamental agreement on the importance of free banking.

Born to a family of merchants in Dunkerque (northern France), Charles Coquelin (1802-1852) graduated from the Paris Faculty of Law. He became a lawyer but rapidly turned toward political economy. He founded a short-lived journal of commercial law in the late 1820s. In the early 1830s, he briefly worked as a journalist for a variety of newspapers. After publishing an article on commercial freedom in 1846, he joined the board of a free trade association (Association pour la liberté des échanges) founded by Frédéric Bastiat, who was a close friend. He unsuccessfully ran for the French Assembly in 1848 as an antisocialist. From 1847, Coquelin regularly contributed to the Journal des économistes, and ended up editing the Dictionnaire, for which he wrote several entries. ${ }^{11}$

If Coquelin's background caused him to view the economy as a set of legal commitments, Jules Dupuit's background as an engineer-economist would cause him to see the economy as a system with clear and consistent rules. Born in Fossano in the Italian region of Piedmont, Jules Dupuit (1804-1866) was trained as an engineer in two of the most prestigious scientific schools in France, École Polytechnique and École des Ponts et Chaussées. Until 1849, Dupuit was in charge of the roadways and navigation projects in various regional posts. During that period, he developed his expertise on the

\footnotetext{
${ }^{9}$ It should be noted that during the SEP meetings, the participants gave their opinions in response to a specific question on the agenda. The opportunity to get into the specifics of a subject matter or tackle related issues was necessarily limited. As for La liberté commerciale, the book was first and foremost a panegyric for free trade. The main message conveyed in the book was that money is at the service of trade and not the other way around. Dupuit's monetary views are exposed over eight chapters in which he defended quantity theoretic positions. There are very few discussions of banking and credit.

${ }^{10}$ For instance, see SEP (1856a, p. 138; 1863, pp. 338-339).

${ }^{11}$ For more biographic details on Coquelin, see Molinari (1852), Nouvion (1908), and Nataf (2006).
} 
utility of public works. In 1850, he was named director and chief engineer in Paris, where he supervised the water supply system and the construction of sewers. His passion for economic questions intensified, and led to numerous publications and an active participation in the monthly SEP meetings. ${ }^{12}$

Coquelin's and Dupuit's personal and professional trajectories allow modern readers to understand what kind of intellectual resources were available to them and, ultimately, why they decided to address banking and credit issues. Coquelin's interest was more pronounced than Dupuit's and traced back to his stint as an economic journalist. Banking quickly came to be his area of expertise. Coquelin's background in law-a similarity that also applied to Macleod — can explain his credit theoretic positions. Coquelin's concern was the "underdevelopment" of the French banking system compared with that of Britain and America. A frequent source of inspiration on this point was the work of the American economist Henry C. Carey (1838) on the credit system of the three countries. Dupuit was a more versatile economist who dedicated his entire professional life to public service. Dupuit's method was to treat political economy as a combined science of reason and observation. Engineering led him to study economic issues through practical questions. His interest in monetary and banking matters materialized in the last decade of his life, mostly through the SEP meetings. Dupuit was one of several French economists who had the failure of John Law's scheme in mind, ${ }^{13}$ which might explain his quantity theoretic positions and his primary concern for the stability of the banking system. Above all, as intellectuals and members of SEP, Coquelin and Dupuit had an interest in banking that was influenced by the economic context characterized by a bimetallic standard, the monopoly of issuing banknotes granted to the Bank of France, and the legal obligation of convertibility on demand. ${ }^{14}$

France experienced bimetallism throughout the most part of the nineteenth century (Breton 1991; Flandreau 1995; Officer 2008; Redish 2006; Wilson 2000). In 1803, the franc became the monetary unit. The official mint ratio was set at 15.5 kilograms of silver for 1 kilogram of gold. Until 1873, the gold-silver market price ratio gravitated around 1/15.5, despite several shocks. In the 1850s, gold inflows significantly increased after the Californian and Australian gold discoveries, putting downward pressure on the market price ratio. In the $1860 \mathrm{~s}$, gold production stagnated, and the exploitation of Nevada silver mines put strong upward pressure on the ratio. But bimetallism stabilized the gold-silver market price ratio. In 1865, Belgium, Italy, Switzerland, and France-later joined by Greece-formed the Latin Monetary Union and adopted a common bimetallism. The bimetallic system ended in the 1870 s, due to Germany's move to a gold standard financed by the French indemnity resulting from the FrancoPrussian War.

\footnotetext{
${ }^{12}$ See Chatzis (2009) for a complete biography.

${ }^{13}$ Dupuit scolded Law in harsh terms: "What we have called financiers ... were con artists who, like the famous Law, claimed to create wealth with certain financial combinations independently from labor and savings... Those financiers abused people who believed in their science as if they believed in magic" (SEP 1865, pp. 292-293).

${ }^{14}$ The possibility to redeem banknotes into metallic money was standard throughout the nineteenth century, but convertibility was suspended between 1848 and 1850, and between 1870 and 1877 (Leclercq 2010).
} 
In the nineteenth century, the banking system was centralized around the Bank of France. The Bank was a private institution that coexisted with commercial banks. In 1803 - three years after being created, the Bank of France received a note-issuing privilege over the Paris region. The monopoly was renewed in 1806, 1840, 1848, and 1852, and extended over all of France as the Bank took over several local commercial banks. This was the backdrop for the controversy between the proponents of free banking (who included Coquelin and Dupuit) and the advocates for a monopoly on the issuance of banknotes to the Bank of France.

Free banking entailed competition among a multiplicity of banks, and full freedom to issue banknotes for every banking institution. ${ }^{15}$ Free banking ideas in France traced back to J.-B. Say's writings. Say criticized the monopoly of the Bank of France. He accused the establishment of being excessively cautious in its credit operations, and of keeping considerable amounts of cash in reserve. Furthermore, Say blamed the establishment for lending only to the wealthy, even when entrepreneurs provided reasonable guarantees. Those criticisms led Say to embrace a pro-free banking stance: "The establishment of several banks, for the issue of convertible notes, is more beneficial than the investment of any single body with the exclusive privilege; for the competition obliges each of them to court the public favor, by being more accommodating and by offering better guarantees" (Say [1803] 2006, p. 574).

However, drawing upon the example of Britain, Say did not think that one could allow several issuing banks to coexist without significant risks. Instead, he anticipated an intermediate solution. The Bank of France would lose its exclusive issuing privilege and would be subjected to the competition of one or two issuing banks. Among those competing institutions, the one that proved most useful in advancing cash to the public would be compensated by greater circulation of its banknotes. The solution, for Say, resided in the regulation of the right to issue banknotes. Say's support for free banking was therefore moderate. Later, free banking advocates were the most dominant in SEP. They were critical of the fact that public authorities tightly regulated interest rates and significantly impeded access to the banking industry. They also criticized the 1844 Bank Charter Act (known as the Peel's Act) that gave a monopoly on the issuing of currency to the Bank of England. Repealing the monopoly of the Bank of France, they maintained, would accelerate the development of the banking system and then stimulate capital accumulation. They considered the central bank monopoly a primary source of economic dysfunction.

\section{ON CREDIT AND THE NOTE-ISSUING MECHANISM}

At first sight, one can assume that Coquelin and Dupuit shared similar views because they both strongly supported free banking. A closer scrutiny of their arguments reveals sharp divergences on their conception of credit and on the note-issuing mechanism. Dupuit and his colleagues addressed these two themes during the SEP meetings of

\footnotetext{
${ }^{15}$ It is important to note, however, that in nineteenth-century France, free banking partisans never advocated the possibility for commercial banks to issue competing currencies in units of their own choosing, a stance later taken by Hayek (1976), for instance.
} 
November 1863 devoted to free banking. I argue that Coquelin's and Dupuit's ideas reflected a broader theoretical opposition between, respectively, a credit theory of money and a monetary theory of credit. The role of non-metallic circulation formed the backbone of the discussions.

\section{On Credit and Capital}

For Coquelin, credit allowed producers to enhance their productive capacities, whereas Dupuit did not believe that credit could create more capital.

Coquelin's reasoning found its source in Say's writings. Starting the third edition of Traité d'économie politique, Say advanced that

some [individuals] sometimes think that credit multiplies capital. This error ... demonstrates an absolute ignorance about the nature and the functions of capital. Capital is always a very real value, and determined in a certain way; because immaterial goods cannot be accumulated. Yet a material good cannot be in two places at the same time, and be used by two persons at the same time. Constructions, machines, provisions, merchandise that constitute my capital, can thoroughly be values that I borrowed: in this case, I run a business with a capital that does not belong to me, and that I rent; but, certainly, the capital that I use is not used by someone else. The person who lends it to me is prevented from the power of working it elsewhere. (Say [1803] 2006, pp. 767-769)

Coquelin firmly believed that the standard process of capital accumulation (from savings to investment) was too slow to generate a sustained growth of the French economy. He considered that a commodity that remained in the hands of its producer could not serve as active capital. It became active when it fell into the hands of an agent who used it as an input for its own production. Coquelin contended that Say's reasoning was correct if one considered only relationships between a lender and a producer. But Coquelin noted that the above-mentioned scenario was in fact the exception (Coquelin 1848, p. 59). The most frequent situations consisted of mutual operations between producers (ibid., p. 60). Producer 1 gave out commodities that he did not use (and that were costly to store) to Producer 2, who used them as inputs. In return, Producer 1 received a commercial paper that could be traded. The outcome of a future trade-money or commodity-would be reinvested in his own business. The whole operation was profitable for everyone. Herein lay the power of credit, according to Coquelin. Credit allowed producers to enhance their productive capabilities and thereby develop the economy. For this reason, credit was capital. Coquelin's thesis is that "it is almost literally correct to allege that credit multiplies capital" (Coquelin 1848 , p. 121). He states, "It is true that credit, because it is much more powerful than the very slow effect of accumulation and savings, almost instantly multiplies capital ... by the only fact that it augments the purchasing power for everyone" (Coquelin 1848, p. 127).

Coquelin also looked into the effects of credit on the condition of workers (Coquelin 1848, pp. 157-167). He postulated that the most effective way to raise wages was to stimulate production, which could be carried out by expanding the sources of credit. Coquelin opposed the subsistence theory of wages, which he considered false and misleading. For him, "the price of subsistence goods does not determine the rate of wages; 
it is essentially the relative abundance of capital" (Coquelin 1848, p. 162). Effectively, capital and labor were complementary factors of production. This means labor demand increased when the price of capital decreased. More credit meant a greater supply of capital, which led to a lower cost of borrowing. As a result, the demand for labor would rise and drive up wages: "The rise in wages is simply the consequence and the symptom of credit expansion" (ibid.). Workers' gains, he added, were not detrimental to industrialists in the end. Workers received better wages, but the lower profitability was more than compensated by an acceleration of the production cycle. Businesses benefited from more opportunities to make profits. By and large, the reward of labor grew without harming other classes, thanks to the beneficial influence of credit.

Dupuit presented a different approach of the relationship between credit and capital. In his mind, credit did not increase but only displaced capital. Capital did not arise from credit, but rather from savings. Like Say, Dupuit emphasized that the supply of credit was merely an advance of capital on the market for loanable funds. The supplier (saver) was deprived of funds that the demander (borrower) received; more importantly, Dupuit focused on the consequences of an increase in credit currency on the purchasing power. Credit operations from banks had a neutral impact overall. An increase in the number of loans was indeed a zero-sum game that contributed to increasing the capital of some individuals in nominal terms. But as prices went up, it also eroded the purchasing power of other agents and therefore reduced their capital in real terms. Giving out more credit currency only created inflation without boosting the national product and without generating wealth in conformity with the quantity theory. Dupuit concluded that credit transferred capital between individuals, but it was not and could not be considered as capital:

Credit, as high as it can be, does not create the smallest quantity of capital ... especially when the opposite doctrine is vulgarized in the books of some economists. Credit allows the transfer of capital from sterile hands to productive [hands]; credit therefore allows creating wealth ... thus, it is very useful to society, but credit is not capital. Banks that issue notes in fact enlarge their capital ... but in the same time issuing banknotes augments the value of everything, which reduces an equivalent amount of capital for those who hold cash. (SEP 1863, pp. 338-339)

Although expressing a minority point of view, Dupuit was not completely isolated. Michel Du Puynode used similar arguments (Du Puynode 1850, p. 158; 1853, pp. 110-112; 1863, pp. 106-109). Furthermore, Coquelin and Dupuit omitted consumer credit in their discussion. ${ }^{16}$ They solely focused on credit for production.

\section{The Note-Issuing Mechanism}

Like most French liberals, Coquelin and Dupuit considered only gold and silver as true money in accordance with their metallist conception. Very few conceived of banknotes as money (Breton 1991). In a context of convertibility, banknotes were essentially promises to pay in metallic money on par and on demand. In an idea that descended directly

\footnotetext{
${ }^{16}$ It should be noted that in nineteenth-century France, consumer credit-long-term loans to individualswas limited. The use of consumer credit took off in the 1950s (Gelpi and Julien-Labruyère 1994; Effosse 2014).
} 
from Say, banknotes were thought of as representative signs (signes représentatifs) particularly convenient for large transactions because they were lighter to carry. However, Coquelin and Dupuit envisioned the issuing of banknotes in a different fashion. Coquelin thought that it was unnecessary and counterproductive to tie the issuance of banknotes to the quantity of metallic reserves. He thus championed discretionary latitude for bankers. Banknotes were considered to be instruments of credit (Coquelin 1852a, p. 120). For his part, Dupuit warned against the excessive issuing of banknotes that could affect their value. This led him to suggest a public role in banking.

Coquelin and other liberals like Michel Chevalier and Joseph Garnier were very critical of a disposition of the Bank Charter Act that compelled the Bank of England to issue banknotes fully backed by gold. They highlighted the fact that the Act was suspended on three occasions during the crises of 1847, 1857, and 1866. Capping the issuance of banknotes deprived producers of much-needed funds in times of crisis: that is, when the demand for cash peaked. Yet, the Bank of England gold reserves were at their lowest levels in those times. The Bank Charter Act therefore allowed a large circulation of banknotes when gold abounded and was drastically reduced when gold was scarce; hence, the temporary suspensions so the Bank could recover its freedom of issue in order to ease panic and restore confidence. Consequently, Coquelin concluded that the Bank Charter Act failed to prevent and mitigate economic crises.

Following this line of thought, Coquelin underlined that, a priori, no fixed proportion between bank reserves and quantity of banknotes issued was desirable or necessary. It all depended on multiple parameters and the decision was to be left at the discretion of the banker: "[T] here is no need to set a fixed proportion between the metallic reserves from a bank and the amount of notes to be issued. It essentially depends upon the importance of the establishment, the extent of his credit, and the environment in which it operates, and many other circumstances very difficult to enumerate" (1848, pp. 186-187).

It should be noted that the Bank of France, unlike the Bank of England, was not subject to any legal obligation with respect to metallic reserves, let alone an obligation to issue banknotes fully backed by gold. The customary practice of the Bank of France was to back one-third of issued banknotes with metallic reserves. That number, too, was considered arbitrary and unjustified by Coquelin (1848, p. 186). His stance for an unrestricted freedom of issue was based on the idea that the right amount of banknotes was commensurate with the needs of circulation: i.e., by the demand side. It was therefore arbitrary to restrict the issuing of banknotes to $x \%$ of metallic reserves, a number that did not reflect the actual needs of merchants, which in fact fluctuated from one place to another, from one market to another. ${ }^{17}$ Coquelin never considered overissue to be a problem. ${ }^{18}$ It should be noted that he was consistent on this issue. Thus, Coquelin ruled out overissue as the true cause of economic crises (see section IV).

\footnotetext{
${ }^{17}$ In a similar spirit, Courcelle-Seneuil $(1853,1866)$ also popularized free banking ideas and unrestricted fractional reserve banking. He supervised the publication of the second and third editions of Coquelin's Du crédit et des banques - the new title became Le crédit et les banques-for which he wrote the introduction and added notes to the original text.

${ }^{18}$ In a similar fashion, the modern literature on free banking considers overissue to be non-problematic. For instance, White ([1995] 2008, p. 2) postulates that the "reflux" of excess banknotes occurs either through direct customer redemption or through redemption demands from other banks. A second possibility involves an interbank clearing mechanism. This latter mechanism is nowhere to be found in Coquelin's writings.
} 
Dupuit did not go as far as embracing a mechanical relationship between the amount of banknotes and metallic deposits. However, he clearly warned against the excessive issuing of banknotes. Thus, Dupuit did not believe that a quantity of banknotes greater than its metallic equivalent in banks reserves constituted a gain in wealth: "Issuing banknotes is not the problem; the difficult part is to find someone who accepts them at face value. There is therefore a natural limit to the issuing of banknotes" (SEP 1863, p. 340). In effect, in the context of convertibility, individuals were willing to use banknotes on the premise that they could be traded for gold at any time. Confidence was consequently a key factor. Dupuit derived the conclusion that confidence was inversely proportional to the quantity of metallic money. The more economic agents trusted each other, the less they demanded species (Dupuit 1861, p. 52). Instead, individuals used substitutes like banknotes. In Dupuit's mind, confidence in the bank that issued banknotes stabilized their value. Therefore - this was a distinctive argument in contrast with Coquelin and others - the best way to maintain confidence in the system involved the creation of a public institution that would issue redeemable banknotes in exchange for species on demand (SEP 1863, p. 339). This institution, which would coexist with commercial banks, would not be a bank but an issuing establishment that would back the totality of banknotes issued. It would be an alternative to commercial banks for individuals looking for perfectly secure means of payments. In other words, individuals would have the freedom to choose the "public option," which would offer banknotes fully backed by metallic deposits in case of lack of confidence in the banknotes issued by commercial banks who, for their part, used fractional reserve banking. This suggests that Dupuit, like Coquelin, rightly acknowledged that confidence was never a given in banking; it could come and go. But Dupuit put forward different policy proposals. One could posit that, through his eyes, the "public option" constituted a potential source of stability of the value of the banknotes. This would also be a sort of regulator of the level of confidence between agents. We could conjecture that this "public option" would exert a sort of competitive pressure that would induce some self-control in the issuance of banknotes on the part of commercial banks. This policy recommendation was indicative of his overall stance on public intervention in economic affairs (such as transportation, literary rights), which was related to his engineering background and his profession as a public official. As an engineer of ponts et chaussées, his primary mission was to defend the general interest (intérêt général). Dupuit considered general interest as a notion that transcended private interest (Vatin 2002). Dupuit advocated free trade and competition as long as the general interest was not at play. Otherwise, government intervention was necessary to mitigate market failures. Government intervention could take various forms. In banking, Dupuit's proposal suggested that government would not take over the banking industry or directly compete with commercial banks, but it could be an alternative that, by its only presence, could benefit the industry and thereby society as a whole. This denoted Dupuit's somewhat pragmatic approach of government intervention (Numa 2012, 2013). Dupuit's proposal should also be interpreted as a way to avoid legal constraints similar to those contained in the Bank Charter Act. During the November 1863 meetings, his proposal was singular among the free banking advocates.

A few years later, Henri Cernuschi and Victor Modeste would go further than Dupuit, and defend views combining free banking and 100\% reserve banking. However, they would conceive of banknotes as "false money," an extreme position that Dupuit 
never endorsed. Dupuit did not rank banknotes into money in conformity with his metallist views, but he underlined their convenience as substitutes.

After examining the relationship between credit and capital, and the note-issuing mechanism, I now turn to the potential role of banking in the development of economic crises. Here, too, the role of non-metallic circulation was a central issue.

\section{BANKS AND ECONOMIC CRISES}

French liberals frequently discussed the relationship between monetary factors and economic crises. Because banks were necessarily involved in money and credit operations, they discussed whether banks could somehow be a source of disturbance. Analyzing the relationship between banks and crises entailed an examination of the legal and institutional framework in which banks operated. It was in that context that Coquelin provided a sophisticated crisis theory. He emphasized the role played by banking privileges. Significantly different in nature, Dupuit's contribution rested on the idea that crises were mainly caused by real factors.

The position of many French liberals was that a multiplicity of factors such as revolutions, wars, or famines could potentially cause crises. They also emphasized the role of speculation and monetary factors. Coquelin's contribution is noteworthy for three reasons. His writings contain fierce criticisms of the monopoly of issue granted to the Bank of France. In addition, he predated Clément Juglar in his endeavor to identify the periodic return of crises. ${ }^{19}$ Last, but not least, Coquelin claimed that crises were inherent to the economic system. Coquelin was not the first author to highlight the periodical recurrence of crises, or the first to pinpoint the endogenous nature of their causes. He remains one of the very first, however, to come up with an elaborate explanation of their recurrence. Coquelin defined a crisis as a "sudden disturbance of business that upsets its progress and to a certain extent suspends its course" (1852c, p. 526).

Coquelin remained doubtful toward J.-B. Say's and John Wilson's explanations of crises, which relied on overissue and speculation (Coquelin 1848, pp. 529-530). In Cours complet d'économie politique pratique, Say ([1828-29] 2010, 1, pp. 487-488) analyzed the crisis that took place in England in 1825-26. His main thesis was that it was the consequence of an overissue of banknotes on the part of banking institutions that caused some entrepreneurs to grow their business disproportionately, compared with their capital stock. The growth of the quantity of banknotes generated inflation and depreciated the English currency. Banknote holders panicked and tried to redeem their assets in cash. The Bank of England was forced to purchase gold at any price in order to comply with the legal obligation of convertibility. Faced with mounting losses, the Bank withdrew banknotes from circulation and interrupted its discounting operations. As a result, merchants were deprived of the necessary resources to fund their business. From that point on, the situation took a downward spiral. Merchants were compelled to sell their commodities at a loss. Prices dropped, unemployment rose, and bankruptcies escalated; hence, the origin and the manifestation of the crisis according to Say.

\footnotetext{
${ }^{19}$ On Juglar's thesis, see Besomi (2009, 2010), and also Dal Pont Legrand and Frobert (2010).
} 
Coquelin criticized Say because his scenario, although "certainly carrying some truth in its explanations" (Coquelin 1852c, p. 529), did not account for the true origin of crises. Instead, he posited that banking "privilege almost inevitably leads to the emergence of periodic crises" (Coquelin 1848, p. 212). Up to that point in time, crises, he noted, were principally due to wars, revolutions, or famines. It was therefore easy to identify their causes. Modern crises, however, reached a degree of spontaneity and suddenness never seen before; they had become "almost periodical" (Coquelin 1852c, pp. 526, 528, 530), which necessitated a very different set of explanations. This time, Coquelin asserted, the cause of the disturbance was not external, but inherent to the economic system and closely related to the nature of credit. For Coquelin, credit was the engine of economic activity, but credit required confidence between creditor and debtor. When the level of confidence diminished, individuals doubted that contractual obligations would be fulfilled, which brought a rapid halt to transactions. Coquelin acknowledged that, in addition to credit instability brought about by banking monopoly, misguided production and speculation constituted determining factors in the germination of crises. However, he insisted that the "first cause" (1848, pp. 238, 242; 1852c, pp. 530-531), also called "primordial cause" (1848, p. 242) or "originating cause" (1852c, p. 533), rested upon the existence of privileged banks as they slowly but steadily organized credit rationing, and thus engendered a shortage of financial resources. After a certain time, this cause always produced the same effect-a crisis-whether the determining cause was an abuse of credit or a speculative frenzy.

Coquelin outlined the following process (1848, pp. 223-228): savings previously managed by private lenders and commercial banks could no longer be placed on the capital market. They accumulated without finding a placement, and therefore were temporarily deposited in commercial banks and also in the vaults of the privileged bank at a very low rate of interest. The privileged bank used these deposits to expand its discounts and increase its profits. The situation took a dangerous turn when the privileged bank started lending money that it held only in temporary custody and that could be withdrawn anytime, thus running the risk of becoming overdrawn. Any investment project suddenly became more attractive than the alternative of receiving a very low interest rate. Bank executives and merchants decided to engage in such business opportunities, and quickly attracted the floating capital, which was withdrawn from the bank where it was temporarily deposited. The reserves of the commercial banks disappeared at an accelerated pace. The banks then tried to replenish them by withdrawing their funds from the privileged bank and/or by converting more banknotes. As a result, the metallic reserves of the privileged bank were quickly depleted. The privileged bank was forced to squeeze credit to avoid bankruptcy, which led to the scenario described by Say. All in all, the monopoly of the issuing bank was the recurring root cause. The periodic element of crises resided in the floating capital that slowly accumulated and became overabundant, and that eventually brought about the same effects.

Although crises were related to credit, Coquelin underscored that credit was not harmful. Crises were characterized by a temporary disappearance of credit, but their cause did not lie in credit; it lay in its disappearance. In spite of its apparent sophistication, Coquelin's explanation of the causes and recurrence of economic crises did not account for the return to "normality." In other words, Coquelin did not describe 
a complete cyclical process made of growth and depression periods. Moreover, a critical issue was missing in his argument. Coquelin claimed that a major cause of crisis resided in the legal restrictions on the banking system. But was it the only cause? In other words, in the absence of such restrictions, would the free market (free banking industry) produce a crisis-proof banking system and thus a crisis-proof economy? It may be argued that Coquelin's approach was narrow in focus, albeit consistent overall. This raises questions on the scope of his crisis theory.

For Dupuit, crises were mainly caused by real factors; credit rationing and speculation were totally overlooked in his analysis. The clear difference between Dupuit and most French liberals was that Dupuit analyzed crises in terms of imbalance between production and consumption.

In December 1857, the participants in the SEP meetings analyzed the causes of the crisis that was occurring in Europe and the US after a long period of prosperity. The crisis erupted with the bankruptcy of the Ohio Life Insurance and Trust Company, followed by the collapse of many other financial institutions. The financial panic turned out to be the first "global" economic crisis (Aspers and Kohl 2010). Despite France's relatively mild exposure, compared to that of the US and Britain, many sectors of the French economy were affected. The construction of railroads was slowed, food supply declined, and bankruptcies jumped.

During the SEP session, Dupuit rejected the notion that an economic crisis could be caused by monetary factors. His thinking was a pure application of the neutrality of money. He posited that "the countries affected by this crisis never had as much money as they have today and they certainly have more than when the crisis did not exist. The absence of money could not be considered a cause of the crisis, neither can its abundance be a remedy" (SEP 1857, p. 467). For him, the only reason why crises took place had to do with real variables:

\begin{abstract}
[A]ny crisis, such as the one we are dealing with, is nothing but the result of a fall in output of the truly useful goods. This fall makes them more costly, and the price increase becomes an obstacle ... and sometimes a reason for consuming the savings previously accumulated. As a result, the industries that relied on these savings suffer, and the owners of the remaining savings on the market supply them at a higher rate, as demand is higher than supply. The contrary occurs when output becomes abundant in relation to consumption; as the price of each commodity falls, savings become easy and abundant, and the rent of money drops. In those circumstances, the quantity of money remains unchanged and does not have any influence on the financial situation of the country. The cause of the current crisis is nothing but an output fall over the recent years. (ibid.)
\end{abstract}

In the goods market, output fell; demand was greater than supply and therefore prices went up. Then, in the market for loanable funds, households reduced their supply of savings. ${ }^{20}$ As the demand for loanable funds on the part of businesses was

\footnotetext{
${ }^{20}$ Dupuit's reasoning was concerned with subsistence goods ("useful goods"). As for non-subsistence goods, Dupuit noted in La liberté commerciale (ch. 21) that in years of scarcity of corn, the consumption of bread by the rich remained constant and their consumption of other goods grew, while the low-income class reduced its consumption of bread and other goods overall.
} 
higher than the actual supply, the rate of interest climbed up. ${ }^{21}$ Dupuit assumed that demand for savings from businesses remained unchanged despite a higher interest rate. This was a questionable hypothesis in a period of economic downswing. It could be contended that investment was likely to fall as output was reduced. Facing a higher cost of borrowing, producers would reduce their demand for loanable funds.

For Dupuit, the root cause of economic recessions started with the market for goods. They occurred because production was less than consumption. It subsequently affected the labor market in that the level of employment fell. His leitmotiv was that the lack of production was the true cause of economic disturbance (SEP 1856b, 1857). ${ }^{22}$ Dupuit acknowledged that wars, considered by many as a cause of crisis, in fact led to an imbalance between production and consumption. Thus, he pointed out, wars reduced labor supply, as many soldiers-who were workers - did not return from the battlefield, and subsequently the lack of manpower induced an output decline. Dupuit also indicated that, when gold production was limited to a small number of countries, gold imports could aggravate an ongoing crisis by affecting the redistribution of wealth from gold-producing areas (Australia and California) to non-gold-producing countries like France (SEP 1857, p. 472; 1858, p. 307). Non-gold-producing countries imported gold in exchange for commodities that, in becoming scarcer, rose in price. Dupuit saw the outflow of commodities as synonymous with a fall of output, which created an imbalance between production and consumption. But this scenario was not described as a cause of crises, just an aggravating factor. Altogether, the message conveyed was that banking did not improve real variables. In a rare passage of La liberté commerciale that deals with banking, Dupuit intimated that "all the possible banking systems cannot increase the number of workers or their productivity" (Dupuit 1861, p. 53). His reasoning relied on the quantity theory. For him, the inevitable consequence of a greater abundance of species or banknotes could only drive up the nominal value of all goods.

Like most of his fellow economists, Coquelin designated the monetary sector as the principal source of economic crises as opposed to the real sector in Dupuit's analysis. Dupuit proposed a generic explanation of crises. His approach, built around an imbalance between production and consumption, represented the minority opinion. For example, in the Dictionnaire, aside from the entry Débouchés taken from Say's Cours and a brief allusion in the entry for Consommation by Joseph Garnier, the imbalance between production and consumption approach was blatantly disregarded. ${ }^{23}$ Besides, Dupuit's arguments relative to the relationship between non-metallic circulation and crisis can be criticized. On the one hand, he rejected the notion that an economic crisis

\footnotetext{
${ }^{21}$ The former minister of finances Hippolyte Passy agreed with Dupuit: "[I]n a nutshell, what characterizes the current crisis is the lack of capital funds and the disproportion between savings and [government] prior commitments" (SEP 1857, p. 469).

${ }^{22}$ The rural economist Léonce de Lavergne was one of the rare participants who thought similarly to Dupuit that crises were caused by "a temporary disequilibrium between production and consumption" (SEP 1857, p. 466). However, unlike Dupuit, he posited that the imbalance was caused either because production significantly increased or because consumption diminished.

${ }^{23} \mathrm{An}$ important point must be noted. The vast majority of French authors who attempted to explain crises flatly ignored the so-called Say's law. It is nowhere to be found in the writings of Coquelin and Juglar, for instance. It was not mentioned during the various meetings of SEP dedicated to economic crises. One exception was Garnier (1859, p. 923), who mentioned it in one paragraph.
} 
could be caused by monetary factors; on the other hand, he warned against the overissue of banknotes on the premise that it could affect their value and jeopardize confidence, as explained in section III. One may contend that the latter proposition was tantamount to implicitly acknowledging that monetary disturbances could occur and possibly lead to systemic crises.

\section{CONCLUDING REMARKS}

Coquelin and Dupuit both pushed for free banking. They undoubtedly believed, like most classical economists, that production was the principal factor of economic prosperity. However, they imagined different means to achieve that goal. The main points developed in this article are summarized in Table 1.

I have shown that Coquelin formulated a credit theory of money, whereas Dupuit defended a monetary theory of credit. Coquelin conceived of credit as the most effective way to spur economic development. His reasoning was rooted in unrestricted fractional reserve banking and discretionary latitude for bankers. Credit, in Dupuit's mind, only displaced but did not create additional capital. He warned against the excessive issuing of banknotes. The theoretical underpinnings of Dupuit's views pertain to the quantity theory. I suspect that Coquelin, like many French economists of the time, believed in the law of reflux, also called "law of immediate reimbursability" (SEP 1863, p. 334): the supply of banknotes adjusted to demand without affecting prices, given that the excess of banknotes, if any, returned to the issuer. It may also be argued that Coquelin was more free-market oriented than Dupuit on banking, considering that his views were completely devoid of public involvement. In his History of Economic Analysis, Schumpeter mentioned Macleod as the first modern author to formulate a credit theory of money. A closer examination of Coquelin's ideas has demonstrated that, in fact, he deserves to be mentioned as a forerunner. Coquelin, but also Macleod and Jean-Gustave Courcelle-Seneuil, all supported free banking based on the tenets of fractional reserve banking. It is worth noting that they also had in common the fact that they were all trained as lawyers before turning to political economy. Their background in law undoubtedly forged their belief that credit was primarily a transferrable right.

As is often the case with competing paradigms, the truth lies in the middle. Both Coquelin and Dupuit touched upon part of the truth, but neither had it all.

Table 1. Coquelin and Dupuit on banking and credit: a summary

\begin{tabular}{|c|c|c|}
\hline & COQUELIN & DUPUIT \\
\hline Paradigm & Credit Theory of Money & Monetary Theory of Credit \\
\hline Banking & $\begin{array}{l}\text { Creator of monetary substitutes } \\
\text { Agent of production }\end{array}$ & $\begin{array}{l}\text { Intermediary of loanable funds } \\
\text { Agent of circulation }\end{array}$ \\
\hline Credit & $\begin{array}{l}\text { Enhances productive capacities } \\
\text { Win-win situation }\end{array}$ & $\begin{array}{l}\text { Only displaces capital } \\
\text { Zero-sum game }\end{array}$ \\
\hline Mechanism of issue & $\begin{array}{l}\text { No arbitrary restriction: needs } \\
\text { of circulation }\end{array}$ & $\begin{array}{l}\text { No restriction (commercial banks) } \\
100 \% \text { reserve } \\
\text { (public issuing body) }\end{array}$ \\
\hline
\end{tabular}


Their perspectives were different. Their conflicting views illustrate the opposition of elasticity vs. scarcity (Mehrling 2013). On the one hand, Coquelin's concern was to accelerate the economic development of France. One possibility to achieve that goal was to explore new funding opportunities between individuals through debts and claims. Thus, Coquelin focused on the elasticity of credit. On the other hand, Dupuit focused on the stability of the banking system, which was achieved through the scarcity of money. In other words, discipline was the sine qua non in the conduct of banking and monetary affairs. Hence, two paradigms associated with credit: one drew upon the creation of monetary substitutes, the other was based upon real savings. In the former, banks played the role of quasi-agents of production; in the latter, only savings previously constituted by the lender could be transferred to the borrower. Banks were agents of circulation.

The article has brought to the fore a significant divergence on the role of banking in economic crises. Coquelin pointed toward bank privileges and their subsequent practices as a cause of crises. Dupuit denied that banks had any role in triggering crises, but concentrated his arguments on the imbalance between production and consumption.

The SEP brought together intellectuals who coalesced around Say's tradition. Nevertheless, this learned society was not a monolith. Some questions were intensely debated with divergent views, even among economists who agreed on a common objective like free banking. Regarding Dupuit, his positions made him a loose cannon in the eyes of many French liberals. The deterioration of his relationship with some SEP members might explain why he joined another learned society in 1863, the Société internationale des études pratiques d'économie sociale, while still attending the SEP meetings (Breton and Klotz 2009).

\section{REFERENCES}

Arena, Richard. 2001. "Jean-Baptiste Say and the French Liberal School of the Nineteenth Century: Outside the Canon?" In Evelyn Forget and Sandra Peart, eds., Reflections on the Classical Canon in Economics. New York: Routledge, pp. 205-223.

Arnon, Arie. 2011. Monetary Theory and Policy from Hume and Smith to Wicksell: Money, Credit, and the Economy. New York: Cambridge University Press.

Aspers, Patrik, and Sebastian Kohl. 2010. "Economic Theories of Globalization.” In Bryan S. Turner, ed., The Routledge International Handbook of Globalization Studies. New York: Routledge, pp. 42-61.

Besomi, Daniele. 2009. "Clément Juglar and His Contemporaries on the Causes of Commercial Crises." Revue européenne des sciences sociales 47 (143): 17-47.

—. 2010. "'Periodic Crises': Clément Juglar between Theories of Crises and Theories of Business Cycles." Research in the History of Economic Thought and Methodology 28 (A): 169-283.

Breton, Yves. 1991. "La monnaie, le crédit, et la banque en France." In Yves Breton and Michel Lutfalla, eds., L'économie politique en France au XIXe siècle. Paris: Economica, pp. 525-553.

Breton, Yves, and Gérard Klotz. 2009. Jules Dupuit: Euvres économiques complètes. Paris: Economica.

Breton, Yves, and Michel Lutfalla. 1991. L'économie politique en France au XIXe siècle. Paris: Economica.

Carey, Henry Charles. 1838. The Credit System in France, Great Britain, and the United States. Philadelphia: Carey, Lea, \& Blanchard.

Carr, Jack L., and Frank Mathewson. 1988. "Unlimited Liability as a Barrier to Entry.” Journal of Political Economy 96 (August): 766-784.

Cernuschi, Henri. 1865. Mécanique de l'échange. Paris: A. Lacroix. 1866. Contre le billet de banque. Paris: Guillaumin. 
Chatzis, Konstantinos. 2009. “Jules Dupuit, ingénieur des Ponts et Chaussées.” In Yves Breton and Gérard Klotz, eds., Jules Dupuit: Euvres économiques complètes. Volume 1. Paris: Economica, pp. 615-692.

Coquelin, Charles. 1842. "Du crédit et des banques dans l'industrie." Revue des deux mondes 31 (July-August): 776-827.

-1848. Du crédit et des banques. Paris: Guillaumin.

. 1852a. "Banque." In Charles Coquelin and Gilbert-Urbain Guillaumin, eds., Dictionnaire de l'économie politique. Paris: Guillaumin, pp. 107-140.

—. 1852b. "Crédit." In Charles Coquelin and Gilbert-Urbain Guillaumin, eds., Dictionnaire de l'économie politique. Paris: Guillaumin, pp. 493-497.

- 1852c. "Crises commerciales." In Charles Coquelin and Gilbert-Urbain Guillaumin, eds., Dictionnaire de l'économie politique. Paris: Guillaumin, pp. 526-534.

Courcelle-Seneuil, Jean-Gustave. 1853. Traité théorique et pratique des opérations de banque. Paris: Guillaumin.

_. 1866. "Le billet de banque n'est pas fausse monnaie." Journal des économistes 3 (9): 342-349.

Cowen, Tyler, and Randall Kroszner. 1989. "Scottish Banking before 1844: A Model for Laissez Faire?" Journal of Money, Credit and Banking 21 (May): 221-231.

Dal Pont Legrand, Muriel, and Ludivic Frobert. 2010. "Le 'prophète des crises.' Économie politique et religion chez Clément Juglar.” Astérion 7. http://asterion.revues.org/1642. Accessed 15 January 2017.

Domin, Jean-Paul. 2007. "La question du monopole d'émission de la monnaie: le débat banque centrale contre banque libre chez les économistes français (1860-1875)." Revue européenne des sciences sociales XLV (137): 185-202.

Dowd, Kevin. 1988. Private Money. The Path to Monetary Stability. London: Institute of Economic Affairs. . 1992. The Experience of Free Banking. New York: Routledge.

Du Puynode, Michel Gustave Partounau. 1850. "Du crédit et des banques par M. Ch. Coquelin.” Journal des économistes 25 (106): 153-160.

-1853. De la monnaie, du crédit et de l'impôt. Volume 1. Paris: Guillaumin.

- 1863. De la monnaie, du crédit et de l'impôt. Volume 1. Second edition. Paris: Guillaumin.

Dupuit, Jules. 1861. La liberté commerciale: son principe et ses conséquences. Paris: Guillaumin.

Effosse, Sabine. 2014. Le crédit à la consommation en France, 1947-1965. De la stigmatisation à la réglementation. Paris: IGPDE/Comité pour l'histoire économique et financière de la France.

Flandreau, Marc. 1995. L'or du monde, la France et la stabilité du système monétaire international 18481873. Paris: L'Harmattan.

Garnier, Joseph. 1859. “Crises commerciales.” In Dictionnaire universel théorique et pratique du commerce et de la navigation. Paris: Guillaumin, pp. 920-925.

Gelpi, Rosa-Maria, and François Julien-Labruyère. 1994. Histoire du crédit à la consommation: doctrines et pratiques. Paris: La Découverte.

Hayek, Friedrich August von. 1976. Denationalisation of Money. London: Institute of Economic Affairs.

Juurikkala, Oskari. 2002. "The 1866 False-Money Debate in the Journal des économistes: Déjà vu for Austrians?" Quarterly Journal of Austrian Economics 5 (4): 43-55.

Leclercq, Yves. 2010. La banque supérieure: la banque de France de 1800 à 1914. Paris: Éditions Classiques Garnier.

Leter, Michel. 2006. "Éléments pour une étude de l’école de Paris (1803-1852)." In Philippe Nemo and Jean Petitot, eds., Histoire du libéralisme en Europe. Paris: Presses Universitaires de France, pp. 429-509.

Macleod, Henry Dunning. 1855. The Theory and Practice of Banking. Volume 1. London: Longmans.

Mehrling, Perry. 2013. "The Inherent Hierarchy of Money.” In Lance Taylor, Armon Rezai, and Thomas Michl, eds., Social Fairness and Economics: Economic Essays in the Spirit of Duncan Foley. New York: Routledge, pp. 394-404.

Modeste, Victor. 1866a. "Le billet des banques d'émission et la fausse monnaie." Journal des économistes 3 (8): 181-212. 
1866b. "Le billet des banques d'émission est-il fausse monnaie?" Journal des économistes 4 (10): 73-86.

Molinari, Gustave de. 1852. "Charles Coquelin.” Journal des économistes 33 (137-138): 167-176.

Nataf, Philippe. 2006. "La vie et l'oeuvre de Charles Coquelin (1802-1852)." In Philippe Nemo and Jean Petitot, eds., Histoire du libéralisme en Europe. Paris: Presses Universitaires de France, pp. 511-530.

Nouvion, Georges de. 1908. Liberté du commerce et des banques. Charles Coquelin: sa vie et ses travaux. Paris: Alcan.

Numa, Guy. 2012. "Dupuit and Walras on the Natural Monopoly in Transport Industries: What They Really Wrote and Meant.” History of Political Economy 44 (1): 69-95.

- 2013. Réglementations et concurrence dans les chemins de fer français 1823-1914. Paris: Éditions Classiques Garnier.

Officer, Lawrence Howard. 2008. "Bimetallism.” In Steven Neil Durlauf and Lawrence Edward Blume, eds., The New Palgrave Dictionary of Economics. New York: Palgrave Macmillan, pp. 488-492.

Poinsot, Philippe. 2011. "Jules Dupuit économiste: de l'oubli à l'édition complète de ses Euvres." Cahiers d'économie politique 60 (1): 205-215.

Redish, Angela. 2006. Bimetallism: An Economic and Historical Analysis. New York: Cambridge University Press.

Say, Jean-Baptiste. [1803] 2006. Traité d'économie politique. Édition variorum. Paris: Economica.

— [1828-29] 2010. Cours complet d'économie politique pratique. Édition variorum. Paris: Economica.

Schumpeter, Joseph Alois. 1954. History of Economic Analysis. New York: Oxford University Press.

Schwartz, Anna. 1989. "Banking School, Currency School, Free Banking School." In John Eatwell, Murray Milgate, and Peter Newman, eds., The New Palgrave: Money. New York: W.W. Norton, pp. 41-49.

Sechrest, Larry James. 1988. "White's Free Banking Thesis: A Case of Mistaken Identity." Review of Austrian Economics 2 (1): 247-257.

- 2008. Free Banking. Theory, History, and a Laissez-Faire Model. Auburn: The Ludwig von Mises Institute.

Silvant, Claire. 2010. "L'école libérale française et l'intervention publique dans la deuxième moitié du XIXe siècle.” PhD diss. Université Paris-Ouest-Nanterre-La Défense.

Smith, Vera Constance. 1936. The Rationale of Central Banking. London: P. S. King.

Société d'économie politique. 1856a. "Influence du prix des vivres et de l'abondance de l'or sur les salaires.” Journal des économistes, séance du 5 avril, 10 (28): 138-143.

—. 1856b. "Causes de la crise financière." Journal des économistes, séance du 6 octobre, 12 (34): $152-153$.

. 1857. "Origines et causes de la crise actuelle.” Journal des économistes, séance du 5 décembre, 16 (48): 465-473.

—. 1858. "De la crise actuelle. De l'extrême abondance et de l'extrême rareté des métaux précieux." Journal des économistes, séance du 5 février, 17 (2): 301-313.

—. 1863. "Sur la liberté des banques et la libre émission des billets à vue et au porteur." Journal des économistes, séance du 5 novembre, 40 (11): 321-343.

—. 1865. "De la science financière (suite et fin)." Journal des économistes, séance du 5 juin, 47 (140): 292-302.

Vatin, François. 2002. "La morale utilitaire de Jules Dupuit.” In Jean-Pascal Simonin and François Vatin, eds., L'œuvre multiple de Jules Dupuit (1804-66): Calcul d'ingénieur, analyse économique et pensée sociale. Angers: Presses Universitaires d'Angers, pp. 91-116.

White, Lawrence Henry. [1995] 2008. Free Banking in Britain. Theory, Experience and Debate: 18001845. London: Institute of Economic Affairs.

Wilson, Ted. 2000. Battles for the Standard: Bimetallism and the Spread of the Gold Standard in the Nineteenth Century. Burlington: Ashgate. 